\title{
Menata Impresi dengan Angka Kemiskinan
}

\author{
Saortua Marbun ${ }^{1}$ \\ ${ }^{1}$ Sekolah Tinggi Ilmu Ekonomi Triatma Mulya
}

October 9, 2018

\section{Menata Impresi dengan Angka Kemiskinan}

Saortua Marbun (Marbun, 2018)

25 Januari 2018

Rasul Yohanes menulis pada pasal 12 ayat 3-8. Maria, saudari Lazarus, "mengambil setengah kati minyak narwastu murni yang mahal harganya, lalu meminyaki kaki Yesus dan menyekanya dengan rambutnya; dan bau minyak semerbak di seluruh rumah itu. Tetapi Yudas Iskariot, berkata: "Mengapa minyak narwastu ini tidak dijual tiga ratus dinar dan uangnya diberikan kepada orang-orang miskin?" Hal itu dikatakannya bukan karena ia memperhatikan nasib orang-orang miskin, melainkan karena ia adalah seorang pencuri; ia sering mengambil uang yang disimpan dalam kas yang dipegangnya. Maka kata Yesus: "Biarkanlah dia melakukan hal ini mengingat hari penguburan-Ku. Karena orang-orang miskin selalu ada pada kamu, tetapi Aku tidak akan selalu ada pada kamu."

"Tindakan Maria ini merupakan suatu pengorbanan besar, karena minyak narwastu murni itu sangat mahal harganya. Maria sadar bahwa kesempatan untuk mengungkapkan pengabdian kepada Yesus segera akan berakhir, karena itu dia memanfaatkan kesempatan yang tersedia. Iman dan pengabdiannya kepada Tuhan merupakan teladan tertinggi dari apa yang diinginkan Allah dari orang percaya." (sab, a)

Undang-Undang Dasar 1945 menyebutkan bahwa "Fakir miskin dan anak-anak terlantar dipelihara oleh negara." (Subekan, 2014) Itu betul. Wajar pula bila ada oknum selaku "negarawan" menaruh peduli pada "angka kemiskinan". Namun demikian, perhatian tersebut dapat dimaknai "terbalik" apabila dilontarkan dalam konteks "kontestasi politik" misalnya menjelang pilkada dan pilpres. Kata kunci "miskin, petani, nelayan" kerap muncul sebagai "lipstick" atau bedak penghias paras. Mengulas angka kemiskinan dengan segudang kepentingan. Mengelola impresi sembari memanfaatkan sorotan kamera. Sadar bahwa "komentar" tersebut disaksikan banyak orang. Tidakkah hal itu mirip dengan kemunafikan Yudas Iskariot? Tentu saja, "si miskin, si fakir, si anak terlantar" - tidak berdaya menolak sekali pun "kata kunci" itu dikapitalisasi, dipolitisir.

Oknum memperkuat argumennya dengan data kemiskinan yang dirilis Badan Pusat Statistik. Katanya Maret 2017 penduduk miskin ada 27,77 juta jiwa, sekitar 17,10 juta jiwa di antaranya berada di desa. (BPS, 2017) Data itu, lalu dibandingkan dengan angka periode sebelumnya, katanya semakin parah. Ujung-ujungnya pemerintah "katanya" belum berhasil. Timpang di sana-sini, "katanya". Sekilas memberi kesan menarik dan meyakinkan. Namun, bila dicermati secara kritis "impresi" itu mirip dengan kemunafikan Yudas Iskariot. Ucapan dan niatnya tidak selaras. Wacana kepedulian terhadap si miskin ibarat peribahasa yang berkata, "telunjuk lurus, kelingking berkait." Tampaknya baik, tetapi hatinya diragukan.

Di pihak lain, ada "oknum" yang secara sukarela, melaksanakan pengobatan gratis, memberi bantuan secara 
swadaya. Mereka tidak melibatkan media, tidak bersuara, tentu saja informasinya tidak meluas diketahui publik. Kontras dengan oknum yang lihai melipat kelingking seraya meluruskan telunjuk - menuding dengan "maksud" yang dapat dipahami pemirsa.

Perempuan bernama Maria meminyaki kaki Kristus di Kota Betania. Sebuah kota di mana Lazarus pernah dibangkitkan oleh Yesus dari kematian. Mujizat yang terjadi di sana membuat tempat itu menjadi masyhur. Ketika Yesus tiba di Betania, diadakan perjamuan sebagai sambutan untuk Dia. Maria pun menunjukkan rasa hormat dan rasa syukur karena kematian dan kebangkitan kakak lelakinya, Lazarus. Minyak setengah kati (setengah liter) seharga 300 Dinar dipersembahkan kepada Yesus, sebagai persembahan yang terbaik. Persembahan yang termahal, karena harganya setara dengan upah seorang pekerja selama 300 hari.

Yesus Kristus tidak keberatan atas perbuatan Maria. Akan tetapi, Yudas Iskariot tampaknya gagal memahami makna tertinggi dari perbuatan Maria. Yudas melontarkan kritik seraya berkata, "Mengapa minyak narwastu ini tidak dijual tiga ratus dinar dan uangnya diberikan kepada orang-orang miskin?" Bagi Yudas, perbuatan Maria itu adalah suatu "pemborosan" - dan ia tidak bisa mengerti, "Mengapa Yesus membiarkan hal itu?" "Apakah Yesus tidak lagi memperhatikan orang-orang miskin?"

Menurut Matthew Henry, "Yudas, seorang dari murid-murid Yesus bersungut-sungut atas tindakan Maria. Memang tidak aneh bila orang-orang yang paling jahat menyamar di balik pengakuan iman mereka yang terbaik. Banyak orang berpura-pura mengaku mengenal Kristus, padahal mereka sama sekali tidak mengasihiNya. Yudas adalah seorang rasul, seorang pengkhotbah Injil, tetapi ia malah berkeberatan dan mencela perbuatan yang menunjukkan kasih sayang dan pengabdian yang tulus seperti yang dilakukan Maria tadi. Perhatikan, menyedihkan sekali jika kehidupan agama dan semangat yang kudus malah dicerca dan ditolak oleh orang-orang yang justru seharusnya mendorong dan menyokong semuanya itu." (sab, b)

"kasih yang telah mendingin terhadap Kristus dan kebencian tersembunyi terhadap kesalehan yang tulus, bila muncul dalam diri penganut agama, maka ini menjadi pertanda buruk akan terjadinya kemurtadan. Orang-orang munafik yang biasanya tidak mudah tergelincir karena godaan-godaan duniawi, justru lebih mudah jatuh oleh karena godaan-godaan yang lebih besar daripada itu." "rasa amal terhadap orang miskin dijadikan alasan untuk menentang kesalehan yang ditujukan kepada Kristus dan dijadikan kedok untuk menyembunyikan ketamakan." "Keberatan Yudas itu tidak didasari oleh kepeduliannya untuk beramal: Bukan karena ia memperhatikan nasib orang-orang miskin. Dia tidak memiliki belas kasihan terhadap mereka, sama sekali tidak peduli kepada mereka: baginya, orang-orang miskin hanyalah sekedar alat untuk mendapatkan keinginannya, dengan cara berpura-pura memperhatikan mereka." "Keberatan Yudas itu justru muncul karena ketamakannya. Kenyataannya adalah, dia lebih menginginkan minyak narwastu yang dipersembahkan untuk Guru-nya itu supaya dijual saja, lalu uangnya dapat dimasukkan ke dalam kas yang ia pegang, dan setelah itu ia tahu apa yang akan dilakukannya."(sab, b)

Maria tidak berhenti, karena ia melakukannya sebagai tanda kasih. Perbuatan Yesus Kristus yang telah membangkitkan Lazarus tidak dapat dapat dibalas dengan apa pun. Sebagai umat yang beriman, tentu kita pun patut berterima kasih atas kasih dan pengorbanan Kristus bagi kita. Kiranya kita menjadi peniru teladan ketulusan hati Maria. Semoga pula, impresi ala Yudas Iskariot dijauhkan dari anda dan saya. $(*)$

Saortua Marbun

Sekolah Tinggi Ilmu Ekonomi Triatma Mulya

saortuam@gmail.com http://orcid.org/0000-0003-1521-7694

DOI: $10.22541 /$ au.151623860.09427814

(C)2018 Saortua Marbun 


\section{References}

Yohanes 12:3 Versi Paralel Catatan Full Life Study Bible - Tampilan Ayat - Alkitab SABDA. http://alkitab.sabda.org/verse.php?book=43\&chapter=12\&verse=3, a. URL http://alkitab.sabda . org/verse. php?book=43\&chapter=12\&verse=3. Accessed on Wed, January 10, 2018.

Yohanes 12:4 Tafsiran/Catatan Matthew Henry - Tampilan Ayat - Alkitab SABDA. http://alkitab.sabda.org/verse ${ }_{c}$ ommentary 43\&chapter $=12 \&$ verse $=4$, b. URL. Accessed on Wed, January 10, 2018.

BPS. Persentase Penduduk Miskin Maret 2017 Mencapai 10,64 persen. bps.go.id, Juli 17, 2017. URL https://www.bps.go.id/website/images/Kemiskinan-Maret-2017-ind.jpg.

Saortua Marbun. Menata Impresi dengan Angka Kemiskinan - Mimbar Protestan. Surat Kabar Pos Bali, Jan 25 (6), 2018.

Achmat Subekan. FAKIR MISKIN DAN ANAK-ANAK TERLANTAR DIPELIHARA OLEH NEGARA? Badan Pendidikan dan Pelatihan Keuangan - bppk.kemenkeu.go.id, September 22, 2014. URL http://www . bppk.kemenkeu.go.id/. Accessed on Wed, January 10, 2018. 